\title{
POZZOLANIC REACTIONS IN ULTRA-HIGH PERFORMANCE CONCRETE CONTAINING SILICA FUME AND FLY ASH
}

\author{
Padmaja Krishnan ${ }^{1}$, Min-Hong Zhang ${ }^{2}$ and J Y Richard Liew ${ }^{3}$ \\ ${ }^{1}$ ceekp@nus.edu.sg, ${ }^{2}$ ceezmh@nus.edu.sg, ${ }^{3}$ ceeljy@nus.edu.sg \\ Department of Civil and Environmental Engineering, National University of Singapore, \\ Blk E1A, \#07-03, 1 Engineering Drive 2, 117576, Singapore
}

\begin{abstract}
Ultra-high performance concrete (UHPC) generally incorporates silica fume and high cement content with low w/cm. To reduce the cement consumption, fly ash may be used as partial replacement for cement. Since both fly ash and silica fume are pozzolanic in nature, they compete for $\mathrm{Ca}(\mathrm{OH})_{2}$ from cement hydration. This study investigates the effect of $30 \%$ fly ash and $10 \%$ silica fume (as replacement for cement) and their combination on the pozzolanic reactions in pastes and compressive strength of corresponding mortars relevant to UHPC with a low w/cm of 0.19 . Results indicate that there is limited $\mathrm{Ca}(\mathrm{OH})_{2}$ in the paste with a combination of $10 \%$ silica fume and $30 \%$ fly ash at ages of 7, 28, and 56 days. The combination seems to have synergistic effect with the highest compressive strengths at 28 and 56 days in comparison to those of the control mortar and mortars with fly ash or silica fume, which may be explained by the reduced peak rate and cumulative heat of cement hydration at early age resulting in more homogeneous microstructure. The results suggest that additional fly ash as cement replacement beyond $30 \%$ in the UHPC would most likely act as filler.
\end{abstract}

Keywords: Ultra-high performance concrete, pozzolans, silica fume, fly ash

\section{INTRODUCTION}

Since the introduction of Reactive Powder Concrete (RPC) in the 1990s [Richard \& Cheyrezy, 1995], significant effort has been devoted to the development of ultra-high performance concrete (UHPC) worldwide. The UHPCs have found more and more applications in practice.

However, UHPCs generally have high cement contents due to their low water/cementitious materials ratios $(\mathrm{w} / \mathrm{cm})$ and without coarse aggregate. The high cement contents are not only associated with economic and environmental concerns but also have technical implications. Due to the low w/cm, the degree of cement hydration in UHPC is constrained by the availability of water and space. Thus, a large part of the cement remains unhydrated in UHPC. Supplementary cementing materials (SCMs) such as fly ash can be used as partial replacement for Portland cement in such concretes, although this may reduce the strength of the concretes to a certain extent.

However, the pozzolanic reaction of fly ash in UHPC is complicated due to the incorporation of silica fume in most UHPC mixtures. Silica fume is in general an essential component in UHPC due to its smaller particle sizes and high pozzolanic reactivity, which densifies the cement paste matrices and improves the mechanical properties and durability of the concrete. Since both silica fume and fly ash are pozzolanic in nature, they compete for the limited calcium hydroxide $\left(\mathrm{Ca}(\mathrm{OH})_{2}\right)$ produced from cement hydration due to the low $\mathrm{w} / \mathrm{cm}$ in UHPC. Although significant amount of research have examined the contribution of fly ash and silica fume in ternary systems containing cement, fly ash, and silica fume [e.g. Barbhuiya et al. 
2009, Collepardi et al. 2004, Juenger \& Siddique, 2015, Lam et al. 2000, Langan et al. 2002, Mehta et al. 1982, Nochaiya et al. 2010, Thomas et al. 1999, Radlinski \& Olek, 2012, Yazici, 2007, Yu et al. 2015], only limited studies [Korpa et al. 2008, Korpa et al. 2009] are devoted to the pozzolanic reactions in mixtures with low w/cm relevant to UHPC.

The objective of this research is to investigate the effect of $30 \%$ fly ash and $10 \%$ silica fume (as replacement for Portland cement) and their combination on the pozzolanic reactions in cement pastes and the compressive strength of corresponding mortars relevant to UHPC with a low $\mathrm{w} / \mathrm{cm}$ of 0.19 . The mortars were designed for relative comparison without optimizing the particle size distribution, packing density and incorporation of fibers commonly considered in UHPC. This conference paper presents preliminary information on the heat of hydration of paste samples at early age measured by isothermal calorimetry, $\mathrm{Ca}(\mathrm{OH})_{2}$ in the pastes determined by thermogravimetric analyses, and compressive strength of corresponding mortars at ages of 7, 28, and 56 days. These information allows the determination if more fly ash can be beneficially incorporated in the UHPC. More detailed information will be reported later.

\section{EXPERIMENTAL}

\subsection{Mix Proportions and Materials}

Mix proportions of mortars for the compressive strength determination are given in Table 1. The mortars have a w/cm of 0.19 and the cement was replaced with $30 \%$ fly ash, $10 \%$ silica fume, and a combination by mass of cementitious materials with sand content adjusted accordingly. The mix proportions of the cement pastes to determine the $\mathrm{Ca}(\mathrm{OH})_{2}$ was the same as those in Table 1 except for the exclusion of sand.

Ordinary Portland cement (ASTM Type I), dry undensified silica fume, Class F fly ash, and polycarboxylate superplasticizer were used for all the mixtures. Natural sand with a fineness modulus of 3.04 was used for the mortar mixtures. These constituent materials satisfy relevant ASTM standards. 
Table 1. Mix proportions of mortar mixtures $(\mathrm{w} / \mathrm{cm}=0.19)$

\begin{tabular}{|c|c|c|c|c|c|c|c|c|c|}
\hline \multirow[b]{2}{*}{ Mix } & \multirow{2}{*}{$\begin{array}{l}\text { Fly Ash } \\
\text { (FA) (\% } \\
\text { by mass } \\
\text { of CM) }\end{array}$} & \multirow{2}{*}{$\begin{array}{l}\text { Silica } \\
\text { fume } \\
\text { (SF) (\% } \\
\text { by mass } \\
\text { of CM) }\end{array}$} & \multicolumn{6}{|c|}{ Mix proportion $\left(\mathrm{kg} / \mathrm{m}^{3}\right)$} & \multirow{2}{*}{$\begin{array}{l}\text { Flow } \\
\text { value } \\
(\mathrm{mm})\end{array}$} \\
\hline & & & Cement & $\begin{array}{l}\text { Fly } \\
\text { ash }\end{array}$ & $\begin{array}{l}\text { Silica } \\
\text { fume }\end{array}$ & Water & Sand & $\mathrm{SP}^{*}$ & \\
\hline Control & 0 & 0 & 1168 & 0 & 0 & 210 & 1052 & 26.3 & 165.0 \\
\hline SF-10 & 0 & 10 & 1062 & 0 & 118 & 212 & 1020 & 14.3 & 172.0 \\
\hline FA-30 & 30 & 0 & 825 & 354 & 0 & 212 & 948 & 16.1 & 167.5 \\
\hline $\begin{array}{c}\text { FA-30, } \\
\text { SF-10 }\end{array}$ & 30 & 10 & 709 & 354 & 118 & 213 & 907 & 13.7 & 175.0 \\
\hline
\end{tabular}

* 40\% solid content

For each mortar mixture, nine 50-mm cube specimens were cast and moist cured in a fog room at temperatures of $28-30^{\circ} \mathrm{C}$ until the time of testing on the compressive strength following standard procedure of ASTM C 109/C 109M (2016). The cement pastes for the $\mathrm{Ca}(\mathrm{OH})_{2}$ determination were cured in sealed condition at the same temperatures until the specified ages of 7, 28, and 56 days.

\subsection{Test Methods}

\subsubsection{Rate of Heat Development}

The heat generated in cement pastes reflects the rate of cement hydration. Effects of the fly ash and silica fume replacement on the rate of heat generation in cement pastes were evaluated according to ASTM C 1679 by a Thermometric TAM Air 3115 isothermal calorimeter at $30^{\circ} \mathrm{C}$. The calorimeter was conditioned at $30^{\circ} \mathrm{C}$ for one day before measurement, and amplifier range was set at $600 \mathrm{~mW}$. The temperature was selected to simulate temperatures in tropical countries.

Since the dosage of the superplasticizer (SP) can affect the rate of cement hydration, all the four pastes were prepared with the same SP dosage of $2 \%$ by weight of the cementitious materials. About $10 \mathrm{~g}$ of fresh cement pastes prepared were placed in a sample ampoule. The heat recording by the calorimeter started at about $15 \mathrm{~min}$ after the cement was in contact with water and continued for 72 hours. The power output (in milli-watt) from the calorimeter due to the heat generated was recorded, normalized, and converted to heat generated from the sample.

\subsubsection{Thermogravimetric Analysis}

The $\mathrm{Ca}(\mathrm{OH})_{2}$ content is an indicator of cement hydration and pozzolanic reactions of silica fume and fly ash in the paste samples. Samples in the interior of the specimens were obtained at prescribed ages, grinded to powder manually, and placed in isopropanol for at least $30 \mathrm{~min}$, followed by drying in vacuum by means of an aspirator at room temperature to stop cement hydration and pozzolanic reactions and then placed in a vacuum oven at $40{ }^{\circ} \mathrm{C}$ for at least 24 hours. A simultaneous thermal analyzer (Shimadzu DTG $-60 / 60 \mathrm{H}$ ) was used to determine the $\mathrm{Ca}(\mathrm{OH})_{2}$ content by heating a powder sample of about $30 \mathrm{mg}$ in a nitrogen environment from 30 to $950{ }^{\circ} \mathrm{C}$ at a rate of $10^{\circ} \mathrm{C} / \mathrm{min}$. The mass loss due to the decomposition of $\mathrm{Ca}(\mathrm{OH})_{2}$ was determined from the thermogravimetric curve and used to calculate the $\mathrm{Ca}(\mathrm{OH})_{2}$ content, which is expressed as mass percentages of anhydrous sample and mass percentage of cement. The mass of anhydrous cement paste sample was taken as that heated to $600{ }^{\circ} \mathrm{C}$ [Scrivener et al. 
2016]. Three tests were conducted for each paste sample cured for 7 days and the results are consistent. Therefore, only one test was conducted for each sample cured for 28 and 56 days.

\section{RESULTS AND DISCUSSION}

\subsection{Rate of Heat Development}

Figure 1 shows the effect of fly ash, silica fume, and their combination on the rate and cumulative heat development of pastes in comparison to that of the control cement paste without the fly ash or silica fume. For the paste with $10 \%$ silica fume the peak heat rate is reduced due to the decreased cement content whereas the length of dormant period is shortened suggesting acceleration of cement hydration due to the fine silica fume particles acting as nucleation sites. The incorporation of fly ash, on the other hand, reduced the peak rate of heat development and also lengthened the dormant period which can be attributed to the lower cement content in the paste and lower pozzolanic reactivity of the fly ash. When both silica fume and fly ash are present in the mixture, the peak rate of heat development is further reduced due to the reduced cement content as expected, however, the length of the dormant period is comparable to that of the control paste due to the combined effects of silica fume and fly ash. At the end of 72 hours, the cumulative heat is in a descending order of (SF-10) > (FA-30) > (Control) $>$ (FA-30, SF-10).

\subsection{Effect of Silica Fume and Fly Ash on $\mathrm{Ca}(\mathrm{OH})_{2}$ Content in Cement Pastes}

Effects of silica fume, fly ash, and their combination on the $\mathrm{Ca}(\mathrm{OH})_{2}$ content in the pastes are presented in Table 2. Cement hydration generates $\mathrm{Ca}(\mathrm{OH})_{2}$, whereas pozzolanic reactions consumes the $\mathrm{Ca}(\mathrm{OH})_{2}$. The net $\mathrm{Ca}(\mathrm{OH})_{2}$ in the paste is the difference due to these reactions.

The $\mathrm{Ca}(\mathrm{OH})_{2}$ content in the control paste at 7 days is $8.3 \%$, indicating a degree of cement hydration of about $40 \%$ assuming complete cement hydration will generate about 20 weight percent solid calcium hydroxide [Mehta \& Monteiro (2006)]. There is no significant increase in the $\mathrm{Ca}(\mathrm{OH})_{2}$ content from 7 to 28 and 56 days indicating limited cement hydration beyond 7 days for the control paste.

For the paste sample with $10 \%$ silica fume as cement replacement, the $\mathrm{Ca}(\mathrm{OH})_{2}$ at 7 days is $5.9 \%$ by weight of cement, lower than that in the control paste although the rate of cement hydration seems to be accelerated as shown in the calorimeter result. Because of the extremely fine particles and high pozzolanic reactivity, the pozzolanic reaction of silica fume can occur at early age before 7 days, leading to lower $\mathrm{Ca}(\mathrm{OH})_{2}$ in the paste. Similar to that of the control paste, there is no significant change in the $\mathrm{Ca}(\mathrm{OH})_{2}$ content from 7 to 28 and 56 days. This suggests that at such a low w/cm, most of the reactions occur at early age before 7 days.

For the paste with $30 \%$ fly ash as cement replacement, the $\mathrm{Ca}(\mathrm{OH})_{2}$ at 7 days is $11.5 \%$ by weight of cement, higher than that of the control paste $(8.3 \%)$. This is explained by dilution effect since this paste contained less cement than the control paste, and the observation is consistent with that reported in literature [Ramachandran 1982]. Because of its coarser particle sizes, the pozzolanic reaction of fly ash usually occur at later ages, with significant reaction not occurring before 7 days [Weng et al. 1997]. The $\mathrm{Ca}(\mathrm{OH})_{2}$ at 28 days is reduced than that 7 days due to the pozzolanic reaction of the fly ash. Further study is necessary to ascertain if reactions are continued beyond 28 days. 
For the paste with a combination of $10 \%$ silica fume and $30 \%$ fly ash, there is limited $\mathrm{Ca}(\mathrm{OH})_{2}$ at ages of 7,28, and 56 days due to reduced cement content and pozzolanic reactions of silica fume and fly ash. This suggests that additional fly ash as cement replacement beyond $30 \%$ in the UHPC would most likely act as filler.

\subsection{Effect of Silica Fume and Fly Ash on Compressive Strength of Mortars}

The compressive strengths of the mortars corresponding to the pastes discussed above are summarized in Table 3. The control Portland cement mortar shows comparable compressive strengths at 7, 28, and 56 days, and no noticeable increase beyond 7 days. The mortars with $10 \%$ silica fume as cement replacement has higher compressive strength at 7 days due to accelerated cement hydration and higher reactivity of silica fume as discussed earlier but also no significant increase in the compressive strength beyond 7 days. The replacement of cement with $30 \%$ fly ash resulted in $17 \%$ strength reduction at 7 days. However, with continued cement hydration and pozzolanic reaction of the fly ash, the strength of the mortar is increased and reached similar strength as that of the control mortar at 28 days. The incorporation of a combination of $30 \%$ fly ash and $10 \%$ silica fume seem to have synergistic effect with the highest compressive strengths at 28 and 56 days, which may be explained by the reduced peak rate and cumulative heat of the paste (Fig. 1) resulting in more homogeneous microstructure. This is beneficial from environment and technical perspectives.

With the given $\mathrm{w} / \mathrm{cm}$ of 0.19 , the compressive strength in Table 3 seem to show consistent trend as the $\mathrm{Ca}(\mathrm{OH})_{2}$ content discussed in previous section. The additional fly ash as cement replacement beyond $30 \%$ in the UHPC would most likely act as filler, thus reducing the compressive strength due to the reduction in the cement content. Further research is needed to determine the optimum fly ash content in UHPC. As the pozzolanic reactivity of fly ash is affected by the chemical and mineral composition, glass content, particle size distribution etc, the amount of fly ash that can be incorporated in the UHPC may vary depending on the sources of the fly ash. 
Table 2. $\mathrm{Ca}(\mathrm{OH})_{2}$ content of pastes determined by thermogravimetric analysis

\begin{tabular}{|c|c|c|c|c|c|c|c|c|c|}
\hline \multirow{2}{*}{ Mix } & \multicolumn{3}{|c|}{$\begin{array}{c}\text { Cementitious materials } \\
\text { mass } \%\end{array}$} & \multicolumn{3}{|c|}{$\begin{array}{c}\mathrm{Ca}(\mathrm{OH})_{2} \text { content per gram } \\
\text { of anhydrous cementitious } \\
\text { materials, } \%\end{array}$} & \multicolumn{3}{|c|}{$\begin{array}{l}\mathrm{Ca}(\mathrm{OH})_{2} \text { content per } \\
\text { gram of cement, } \%\end{array}$} \\
\hline & Cement & Fly ash & $\begin{array}{l}\text { Silica } \\
\text { fume }\end{array}$ & $7 d$ & $28 \mathrm{~d}$ & $56 \mathrm{~d}$ & $7 d$ & $28 d$ & $56 \mathrm{~d}$ \\
\hline Control & 100 & 0 & 0 & 8.3 & 8.2 & 8.7 & 8.3 & 8.2 & 8.7 \\
\hline SF-10 & 90 & 0 & 10 & 3.8 & 3.4 & 4.6 & 5.9 & 6 & 5.1 \\
\hline FA-30 & 70 & 30 & 0 & 8.0 & 3.9 & 6.0 & 11.5 & 5.6 & 8.6 \\
\hline $\begin{array}{c}\text { FA-30, } \\
\text { SF-10 }\end{array}$ & 60 & 30 & 10 & 1.2 & 1.9 & 1.8 & 1.9 & 2.2 & 3.0 \\
\hline
\end{tabular}

Table 3. Density and compressive strengths of mortar specimens

\begin{tabular}{|c|c|c|c|c|}
\hline \multirow{2}{*}{ Mix } & \multirow{2}{*}{$\begin{array}{c}\text { Average } \\
\text { Density }\left(\mathrm{kg} / \mathrm{m}^{3}\right)\end{array}$} & \multicolumn{3}{|c|}{ Average Compressive Strength (MPa) } \\
\cline { 3 - 5 } & & 7 days & 28 days & 56 days \\
\hline Control & 2335 & 109.3 & 105.7 & 110.7 \\
\hline SF-10 & 2366 & 122.1 & 110.6 & 114.5 \\
\hline FA-30 & 2232 & 89.9 & 103.7 & 104.8 \\
\hline FA-30, SF-10 & 2264 & 105.9 & 114.2 & 122.4 \\
\hline
\end{tabular}

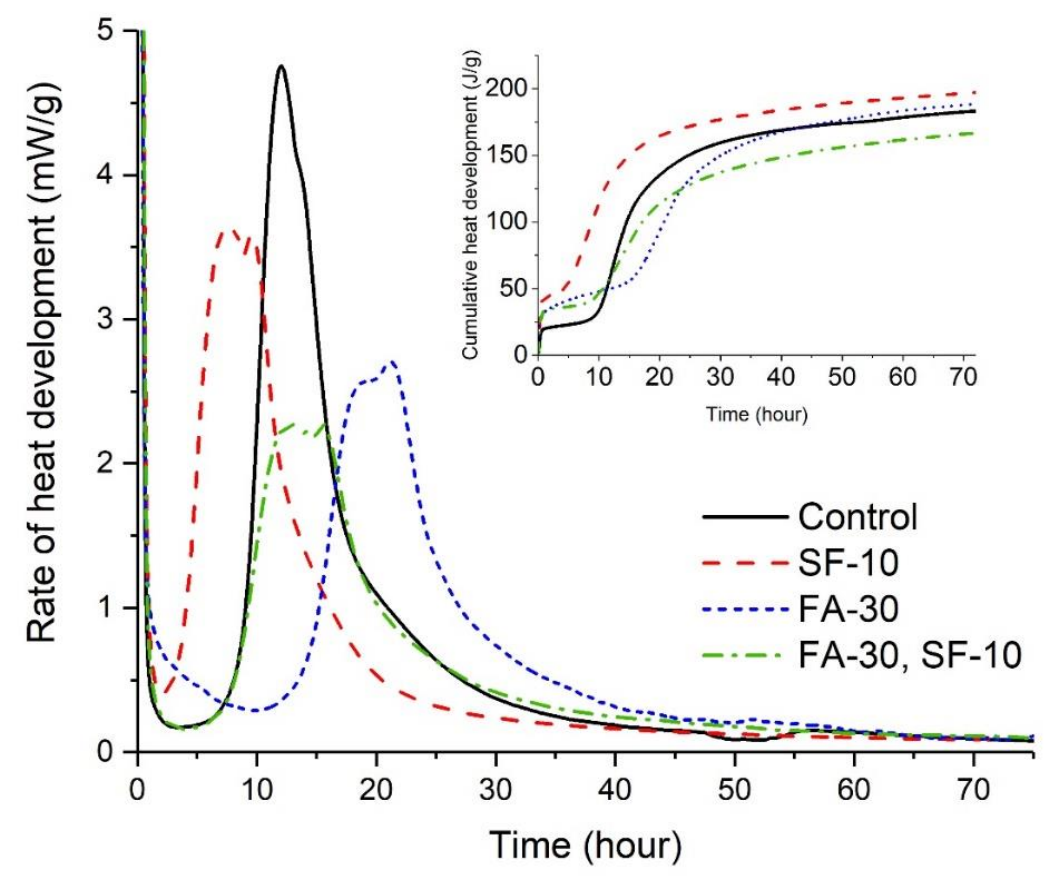

Figure 1. Rate and cumulative heat development of different paste mixtures. 


\section{SUMMARY}

Based on the preliminary information available, it seems that there is limited $\mathrm{Ca}(\mathrm{OH})_{2}$ in the paste with a combination of $10 \%$ silica fume and $30 \%$ fly ash at ages of 7,28, and 56 days due to reduced cement content and pozzolanic reactions of silica fume and fly ash. The combination seems to have synergistic effect with the highest compressive strengths at 28 and 56 days in comparison to those of the control mortar and mortars with fly ash or silica fume, which may be explained by the reduced peak rate and cumulative heat of cement hydration at early age resulting in more homogeneous microstructure. The results suggests that additional fly ash as cement replacement beyond $30 \%$ in the UHPC would most likely act as filler. Given the environmental benefits due to the use of fly ash and reduced cement consumption, the combination may be adopted in UHPC mix design. Further research is needed to ascertain the effect of other limiting factors such as space and water on the pozzolanic reactions.

\section{ACKNOWLEDGEMENT}

The authors would like to acknowledge the financial support by the National Research Foundation (NRF) and SembCorp-NUS Corp Lab under project grant R-261-513-009-281.

\section{REFERENCES}

ASTM C109 / C109M-16a, Standard Test Method for Compressive Strength of Hydraulic Cement Mortars (Using 2-in. or [50-mm] Cube Specimens), ASTM International, West Conshohocken, PA, 2016, www.astm.org

Barbhuiya, S. A., Gbagbo, J. K., Russell, M. I., \& Basheer, P. A. M. (2009). Properties of fly ash concrete modified with hydrated lime and silica fume. Construction and Building Materials, 23(10), 3233-3239.

Collepardi, M., Collepardi, S., Skarp, U., \& Troli, R. (2004, May). Optimization of silica fume, fly ash and amorphous nano-silica in superplasticized high-performance concretes. In Proceedings of $8^{\text {th }}$ CANMET/ACI International Conference on Fly Ash, Silica Fume, Slag and Natural Pozzolans in Concrete, SP-221, Las Vegas, USA (pp. 495-506).

Korpa, A., Kowald, T., \& Trettin, R. (2008). Hydration behaviour, structure and morphology of hydration phases in advanced cement-based systems containing micro and nanoscale pozzolanic additives. Cement and Concrete Research, 38(7), 955-962.

Korpa, A., Kowald, T., \& Trettin, R. (2009). Phase development in normal and ultra high performance cementitious systems by quantitative X-ray analysis and thermoanalytical methods. Cement and Concrete Research, 39(2), 69-76.

Juenger, M. C., \& Siddique, R. (2015). Recent advances in understanding the role of supplementary cementitious materials in concrete. Cement and Concrete Research, 78, 71-80.

Lam, L., Wong, Y. L., \& Poon, C. S. (2000). Degree of hydration and gel/space ratio of highvolume fly ash/cement systems. Cement and Concrete Research, 30(5), 747-756.

Langan, B. W., Weng, K., \& Ward, M. A. (2002). Effect of silica fume and fly ash on heat of hydration of Portland cement. Cement and Concrete research, 32(7), 1045-1051.

Nochaiya, T., Wongkeo, W., \& Chaipanich, A. (2010). Utilization of fly ash with silica fume and properties of Portland cement-fly ash-silica fume concrete. Fuel, 89(3), 768-774.

Mehta, P. K., \& Gjørv, O. E. (1982). Properties of portland cement concrete containing fly ash and condensed silica-fume. Cement and Concrete research, 12(5), 587-595. 
Mehta, P. K., \& Monteiro, P. J. (2006). Microstructure and properties of hardened concrete. Concrete: Microstructure, properties and materials, New York: McGraw-Hill.

Radlinski, M., \& Olek, J. (2012). Investigation into the synergistic effects in ternary cementitious systems containing portland cement, fly ash and silica fume. Cement and Concrete Composites, 34(4), 451-459.

Ramachandran, V. S. (1982). Estimation of $\mathrm{Ca}(\mathrm{OH})_{2}$ and $\mathrm{Mg}(\mathrm{OH})_{2}$-implications in cement chemistry. Israel Journal of Chemistry, 22(3), 240-246.

Richard, P., \& Cheyrezy, M. (1995). Composition of reactive powder concretes. Cement and concrete research, 25(7), 1501-1511.

Scrivener, K., Snellings, R., \& Lothenbach, B. (Eds.). (2016). A practical guide to microstructural analysis of cementitious materials. CRC Press.

Stengel, T., \& SCHIEßL, P. (2009). Life cycle assessment of UHPC bridge constructions: Sherbrooke footbridge, Kassel Gärtnerplatz footbridge and Wapello road bridge. Archit. Civ. Eng. Environ, 1, 109-118.

Thomas, M. D. A., Shehata, M. H., Shashiprakash, S. G., Hopkins, D. S., \& Cail, K. (1999). Use of ternary cementitious systems containing silica fume and fly ash in concrete. Cement and concrete research, 29(8), 1207-1214.

Weng, J. K., Langan, B. W., \& Ward, M. A. (1997). Pozzolanic reaction in Portland cement, silica fume, and fly ash mixtures. Canadian journal of civil engineering, 24(5), 754760.

Yazic1, H. (2007). The effect of curing conditions on compressive strength of ultra high strength concrete with high volume mineral admixtures. Building and environment, 42(5), 2083-2089.

Yu, R., Spiesz, P., \& Brouwers, H. J. H. (2015). Development of an eco-friendly Ultra-High Performance Concrete (UHPC) with efficient cement and mineral admixtures uses. Cement and Concrete Composites, 55, 383-394. 